\title{
The Effectiveness of Multiple Intelligences Based Work Books on Biological Learning Competencies of Students Class X Senior High School
}

\author{
Niken Permata Putri ${ }^{1 *}$ Yuni Ahda ${ }^{2}$ \\ ${ }^{1}$ Student of Master DegreeProgram Biology Department, Math and Natural Science Faculty, Universitas Negeri \\ Padang, Padang, Indonesia \\ ${ }^{2}$ Biology Department, Math and Natural Science Faculty, Universitas Negeri Padang, Padang, Indonesia \\ *Corresponding author.nikenpermataputri@gmail.com
}

\begin{abstract}
During the learning process, teachers have not used workbooks, books used in the learning process, namely books borrowed from the library and Student Worksheets (LKS). LKS used by the teacher has several weaknesses such as the images presented are unclear and have unattractive colors. In addition, the learning process only involves an explanation from the teacher, so that the LKS that has been designed cannot be applied due to time constraints. In the end the students cannot develop the intelligence that exists in themselves which later will affect the learning outcomes of students. To address this problem, a MultiIntelligence Oriented Workbook is developed. The purpose of this study was to develop a Multiple Intelligences Based Workbook and to determine its effectiveness on student learning outcomes in the cognitive, affective and psychomotor domains. This type of research is development using the Plomp model. The Plomp development model consists of three stages of development, namely: the initial investigation phase, the development phase and the prototype phase and the assessment phase. The data collection instruments used were observation sheets and objective questions to measure learning competencies in the cognitive domain. The data analysis technique used to measure the effectiveness of the workbook is the Kolmogrof Smirnov test to test normality, the Levene test to test homogeneity, and the t test to test the hypothesis. The results showed that the use of Multiple intelligences based workbooks during learning had a positive impact on student learning outcomes in cognitive, affective and psychomotor competencies. Learning competencies in the cognitive, affective and psychomotor domains of students using Multiple Intelligencesbased workbooks are better than the learning outcomes of students by using handbooks borrowed from libraries and worksheets commonly used by teachers.

Keywords: Workbook, Multiple Intelligences, Learning Competence.
\end{abstract}

\section{INTRODUCTION}

The curriculum is a set of plans and arrangements regarding the objectives, content, and learning materials as well as the methods used to guide the implementation of learning activities to achieve certain educational goals (Permendikbud no 67, 2013). The 2013 curriculum was developed on the theory of "education based on standards" and competency-based theory theory. Education based on standards stipulates the existence of national standards as a minimum quality of citizens who are broken down into graduate competency standards, teacher and education staff standards, facilities and infrastructure standards, management standards, financing standards and education assessment standards. The competency-based curriculum is designed to provide the widest learning experience for students in developing the ability to behave, be knowledgeable, be skilled and act (Permendikbud no 67, 2013).
One of the subjects in the 2013 curriculum is biology. Biology learning is related to how to find out and understand nature systematically, so that learning biology is not only mastering a collection of knowledge in the form of facts, concepts, principles, but also is a process of discovery. Biology education is expected to be a vehicle for students to learn about themselves and the environment.

However, the reality in the field, learning biology is still less desirable by students get a bad reputation for students and less desirable by most students. The teacher has tried to increase students' interest and understanding of learning biology, but still the efforts made by the teacher were less successful. Factors that influence this may arise from students themselves, teachers who still function as learning resources, and the use of learning media that are still monotonous. The method students feel bored quickly, causing lack of enthusiasm or student interest in participating in learning. 
Based on observations made by the author in several high schools, namely SMA $\mathrm{N} 1$ Rambatan, SMAN 2 Sawahlunto and SMA Muhammadiyah Batusangkar, several problems were found in the learning process at school: First, the relationship of teaching materials used by students in the form of worksheets and biology textbooks. Based on the analysis of textbooks and worksheets, that is, there is no manual in the use of workbooks, activity instructions, follow-up and conclusions. Second, when learning is ongoing, students are less actively involved in the biology learning process, student activity in the learning process is still low. According to students, teaching materials provided by teachers are less attractive, the images are colorless and unclear, and there is no evaluation of each activity. Some of the low student activities that students do are very few students who ask and answer questions and only rely on friends who are smart to work. According to the teacher before the material is taught, students are assigned to record the material to be learned, but students only record the handbook without summarizing and recording all the contents of the book. Third, interviews were also conducted with several students at SMA N 1 Rambat, obtained information that the main learning source for students is textbooks, in general students only have one textbook and one worksheet. Based on the results of interviews with teachers and students, the author tries to provide a solution by developing biology teaching materials in high school, teaching materials developed in the form of workbooks.

Workbooks can make it easier for students to carry out learning activities. One effort to improve the learning process is by activating Multiple Intelligences that exist in students. According to the teacher the activity to activate multiple intelligences was carried out but not yet optimal overall. Aisyah (2016) states that students need to be directed and facilitated to be able to show their ideas systematically. Therefore, the researchers developed multiple intelligences oriented workbooks. Ali, et al (2015) in their research showed that student learning outcomes are better when multiple intelligences theory is part of students' thinking styles, in learning science, mastering science process skills is important for students to gain knowledge applying scientific skills in everyday life they.

The workbook to be developed is Multiple Intelligences oriented. The Multiple Intelligences Theory is a theory that explains some of the intelligence possessed by each human person, it would be better integrated in the form of a workbook so that it can be used as a reference / guide for students in learning.

This workbook not only displays the cognitive domain but also displays other domains such as psychomotor and affective and is integrated with a variety of intelligence that students have. So that in learning students who like to sing will like biology because later they will be presented with songs related to the material presented. Besides that, in integrating Multiple Intelligences in the workbook, researchers will use 8 indicators of the theory of Multiple Intelligences according to Gardned (2011), namely linguistic, mathematical-logical, space-visual, kinestheticphysical, musical, interpersonal, intrapersonal, and environmental indicators.

\section{METHODS}

This type of research is a development research (development research) with the aim of developing a product in the form of a workbook as a solution. The product that will be developed is a workbook which is oriented towards Multiple Intelligences.

Development of Multiple Intelligences oriented workbooks in this study uses the Plomp development plan. This development model consists of three stages of development, namely the initial investigation phase (prelimenary research phase), the development phase and prototype development (development or prototype phase), and the assessment phase (assessment phase). Mckenney (in Plomp, 2013).

The research instrument used was a guide to interviews with teachers and questionnaires to students. The interview guide for the teacher contains several questions about the learning methods used, teaching materials used, and the level of student understanding of the material being taught. The questionnaire given to students contains the availability of teaching materials along with the form of teaching materials used, students' opinions about the material being taught, and ideal teaching materials according to students. This questionnaire is a semi-closed type that has a scale of two, namely "yes" or "no" and is accompanied by a reason. In this questionnaire, only positive items are used to avoid the invalidity of the instruments used. This is consistent with the statement of Schriesheim and Hill (1981) which states that negative items can reduce the validity of the instrument and decrease the response of students for each item.

\section{DISCUSSION}

\subsection{Result}

Based on the results of interviews conducted with educators at SMAN 1 Rambatan and SMAN 2 Sawahlunto data obtained related to the existence of learning workbooks based on the 2013 curriculum. Educators have never developed biology workbooks, educators only use worksheets and handbooks that are only lent from the school library.

Educators explain that when conducting group discussion learning that is carried out, many students look passive and less active in learning, it causes students to think critically in understanding the material cannot be maximized and the difficulty in connecting what has been learned with the circumstances around them. These problems occur because the learning resources provided by educators are not in 
accordance with the needs of students who want active learning and critical thinking in learning. Therefore, the learning process requires a variety of learning materials and media as aids in learning to achieve optimal learning outcomes. Teaching materials also play a role in providing a problem that is directly related to daily life so that later students are able to solve problems and learning becomes active.

Educators really expect the development of biological teaching materials in the form of workbooks that contain various kinds of intelligence related to the learning material. Learning using workbooks is designed to

\section{CONCLUSION}

Learning competencies in the cognitive, affective and psychomotor domains of students using Multiple Intelligences-based workbooks are better than the learning outcomes of students by using handbooks borrowed from libraries and worksheets commonly used by teachers.

\section{REFERENCES}

[1] Abdu, R, 2012. Effects of Problem-Solving Method On Secondary School Students ${ }^{\text {e }}$ Achievement And Retention In Social Studies, In Ekiti State, Nigeria. Journal of

[2] International Education Research - First Quarter. Vol 8 (1), 19-25.

[3] Ajilgoba , S \& Ifamuyiwa A. 2012. A Problem Solving Model as a Strategy for Improving Secondary School Students' achievement and Retention in Further Mathematics. Journal of Science and Technology. Vol 2 (2), 122-130.

[4] Andi Prastowo, 2014. Pengembangan bahan ajar tematik tinjauan teoritis dan praktik. Jakarta: Kencana Prenadamedia Group.

[5] Daryanto, 2013. Menyusun modul bahan ajar untuk persiapan guru dalam mengajar. Yogyakarta: Gava Media.

[6] Haviz, Muhammad. 2013. Research and Development: Penelitian Di Bidang Kependidikan yang Inovatif, Produktif dan Bermakna. Jurnal Ilmiah Ta'dib Vol 16 (1), 2843.

[7] Killen, R, 2009. Effective Teaching Strategies (5 cd), Newcastle: C \& C Offiset Printing Co Ltd.

[8] Plomp, T. 2013. Education Design Research dalam Education Design Research: An Introduction. Ensshede: Netherlands Institute For Curiculum Development.

[9] Purwanto, N.M. 2014. Prinsip-prinsip dan Teknik Evaluasi Pengajaran. Bandung: Remaja Rosdakarya.

[10] Riduwan. 2009. Belajar Mudah Penelitian untuk facilitate students to be able to carry out independent learning activities in accordance with their abilities without having to depend on educators, so that the role of educators in this case changes from providing information to learning facilitators by providing various learning resources and media needed.

Based on the results of interviews with students it is known that students want a workbook in which there is an intelligence that is owned and associated with everyday life so that later students are active in learning and the steps of activities are not complicated and easy to do, have a colored workbook and clear picture.

Guru, Karyawan, dan Peneliti Pemula. Bandung: Alfabeta.

[11] Robert D, \& Barbara L, Wendy W. 2006. Critical Thinking Framework For Any Discipline. International Journal of Teaching and Learning in Higher Education. Vol 17 (2), 160-166.

[12] Syafii, W \& Ruhizan, M,Y. 2013. Problem Solving Skill Learning Achievements Throught Problem-Based Module in Teaching and Learning Biology in Hight School. Journal Asian Social Science. Vol 9 (12), 220-228.

[13] Widjajanti, E. 2008. Kualitas Lembar Kerja Siswa. Jurusan Pendidikan Kimia FMIPA UNY.

[14] Yu Hui Ching. 2009. The Effects of Computer Based Video Strategy Training for Problem Representation and Self-explanation on Undergraduate Students Representing and Solving Ill-Structured Problems. Proquest LLC. 